\title{
PENGARUH ASET PAJAK TANGGUHAN DAN BEBAN PAJAK TANGGUHAN TERHADAP MANAJEMEN LABA
}

\author{
Tiara Timuriana $^{*}$ dan Rezwan Rizki Muhamad ${ }^{* *}$
}

\begin{abstract}
ABSTRAK
Laporan keuangan perusahaan dihasilkan dan disiapkan sebagai pertanggungjawaban manajemen kepada investor sehingga mencerminkan aktivitas perusahaan. kewajiban tersebut tidak terbatas pada kepentingan manajemen tetapi juga untuk kepentingan otoritas pajak. Adanya perbedaan kepentingan dan informasi tersebut memacu manajemen untuk memikirkan bagaimana angka akuntansi yang dihasilkan dapat memaksimalkan kepentingannya. Cara yang dapat dilakukan manajemen untuk mempengaruhi angkaangka akuntansi tersebut dapat berupa manajemen laba melalui aset pajak tangguhan dan beban pajak tangguhan dalam laporan keuangan. Metode pengolahan data yaitu dengan analisis deskriptif statistik dengan alat analisis yaitu regresi linear berganda. Hasil penelitian dapat disimpulkan bahwa: (1) Aset pajak tangguhan berpengaruh terhadap manajemen laba, (2) Beban pajak tangguhan tidak berpengaruh terhadap manajemen laba, dan (3) Aset pajak tangguhan dan beban pajak tangguhan secara bersama-sama berpengaruh terhadap manajemen laba.
\end{abstract}

Kata kunci: Aset pajak tangguhan, beban pajak tangguhan, dan manajemen laba

\begin{abstract}
The financial statements of the company produced and prepared as a management accountability to investors so that it reflects the company's activities. The liability is not limited to management purposes but also for the benefit of the tax authorities. The big difference in the spur interest and information management to consider how accounting numbers generated can maximize its interests. How that can be done to influence the management accounting numbers can be the earnings management through deferred tax assets and deferred tax expense in the financial statements. This study aims to: (1) Describing the effects of deferred tax assets on earnings management in manufacturing companies in Indonesia Stock Exchange 2010-2014. (2) Describe the effect of deferred tax expense on earnings management in manufacturing companies in Indonesia Stock Exchange 2010-2014. (3) Describe the effect of deferred tax assets and deferred tax expense on earnings management in manufacturing companies in Indonesia Stock Exchange 2010-2014. Data processing method is by descriptive statistical analysis with analysis tools that multiple linear regression. Research shows that: (1) Assets Deferred tax effect on earnings management, (2) Deferred tax expense has no effect on earnings management, and (3) Deferred tax assets and deferred tax expense jointly effect on earnings management.
\end{abstract}

Key words: Asset deferred tax, deferred tax expense, and earnings management

\footnotetext{
${ }^{*}$ ) Dosen Tetap Fakultas Ekonomi Universitas Pakuan

${ }^{* *}$ Mahasiswa Fakultas Ekonomi Universitas Pakuan
} 


\section{Pendahuluan}

Laporan keuangan perusahaan dihasilkan dan disiapkan sebagai pertanggungjawaban manajemen sehingga mencerminkan aktivitas perusahaan. Kewajiban tersebut tidak terbatas pada kepentingan manajemen tetapi juga untuk kepentingan otoritas pajak. Kebutuhan dalam Standar Akuntansi Keuangan tidak selamanya sejalan dengan ketentuan perpajakan. Oleh karena itu, Pernyataan Standar Akuntansi Keuangan (PSAK) No. 46 Revisi 2012 Tentang Pajak Penghasilan ini sebagai respon dengan diberlakukannya peraturan pajak penghasilan yang dikeluarkan oleh otoritas perpajakan.

Menurut Sukrisno Agus dan Estralita Trisnawati (2009, 244) aset pajak tangguhan (deffered tax asset) timbul apabila beda waktu menyebabkan terjadinya koreksi positif sehingga beban pajak menurut akuntansi lebih kecil daripada beban pajak menurut peraturan perpajakan. Sedangkan menurut Pernyataan Standar Akuntansi Keuangan (PSAK) No 46 Revisi 2012 menyatakan aset pajak tangguhan adalah jumlah Pajak Penghasilan terpulihkan pada periode mendatang sebagai akibat adanya perbedaan temporer yang boleh dikurangkan dan sisa kompensasi kerugian.

Oleh karena angka-angka akuntansi sangat penting dalam banyak pengambilan keputusan dan laba yang dilaporkan merupakan angka yang memperoleh perhatian paling banyak baik dari pihak internal maupun eksternal, serta digunakan sebagai indikator penilaian kinerja. Perilaku manajemen laba dimungkinkan dapat terjadi karena manajemen mempunyai informasi lebih banyak dan lebih akurat dari pada pihak stakeholder, maka angka ini pulalah yang paling mungkin dimanage oleh manager. Hal tersebut senada dengan yang dikemukakan oleh Irham Fahmi (2014, 517) "manajemen laba (earnings management) adalah suatu tindakan yang mengatur laba sesuai dengan yang dikehendaki oleh pihak tertentu atau terutama oleh manajemen perusahaan (company management)".

Tindakan manajemen laba sebenarnya didasarkan oleh berbagai tujuan dan maksud-maksud yang terkandung didalamnya. Artinya tindakan manajemen laba dilakukan mengandung motivasi-motivasi tertentu, karena tingkat keuntungan atau laba yang diperoleh sering dikaitkan dengan prestasi manajemen, memang sesuatu yang lazim besar kecilnya bonus yang akan diterima oleh manajemen tergantung dari besar kecilnya laba yang diperoleh perusahaan. Selain motivasi bonus motivasi penghematan pajak menjadi motivasi yang paling nyata.

Berbagai pemangku kepentingan (stakeholder) eksternal memiliki kepentingan terhadap kinerja keuangan perusahaan. Misalnya saja, para pegawai dan pelanggan menginginkan perusahaan tetap berjalan dengan baik sehingga dapat bertahan dalam jangka panjang dan melaksanakan kewajiban pensiun. Para pemasok menginginkan jaminan atas pembayaran, dan yang lebih penting lagi adalah bahwa perusahaan pembeli akan menjadi pembeli yang dapat diandalkan selama tahun-tahun kedepan.

$$
\text { Bagi pihak-pihak yang }
$$

berkepentingan itu, tanda-tanda dari kelemahan keuangan, seperti pelaporan rugi, benar-benar merupakan suatu berita buruk. Oleh karena itu, tidaklah mengherankan bahwa dibeberapa perusahaan apabila pada perhitungan awal laporan keuangan menunjukkan indikasi terjadinya kerugian, para akuntannya biasanya diminta untuk 
mempertimbangkan kembali penilaian mereka atas akrual dan estimasi, guna memperoleh angka laba positif dilaporan keuangan perusahaan.

Penilaian atas kebijakan akuntansi akrual dan estimasi akan menghasilkan beban pajak tangguhan, seperti menggeser pendapatan dan biaya. Perusahaan akan menghitung pendapatan berdasarkan metode akrual sedangkan perpajakan akan menghitung pendapatan tersebut setelah kas diterima, oleh sebab itu ketika kas belum diterima oleh perusahaan dalam perhitungan pajaknya masih akan di tangguhkan dalam perhitungan pajak berupa beban pajak tangguhan. Menurut Yulianti (2004, 109) Beban Pajak Tangguhan adalah Timbul akibat perbedaan temporer antara laba akuntansi (yaitu laba dalam laporan keuangan untuk kepentingan pihak eksternal) dengan laba fiskal (laba yang digunakan sebagai dasar perhitungan pajak).

Laba yang dilaporkan manajemen bukan hanya pertanggungjawaban kepada stakeholder saja melainkan untuk kepentingan otoritas pajak juga. Jika laba yang dilaporkan oleh pihak manajemen besar maka hal tersebut juga menjadi berita yang baik bukan hanya bagi stakeholder melainkan bagi pihak otoritas pajak, karena yang dijadikan dasar dalam penghitungan beban pajak adalah laba yang dihasilkan perusahaan. Bila laba yang dihasilkan besar, maka beban pajaknya pun akan besar sehingga dapat mengurangi laba yang akan didapat oleh perusahaan.

Sementara itu penelitianpenelitian sebelumnya pernah dilakukan oleh Yulianti (2005) dengan judul Kemampuan Beban Pajak Tangguhan dalam Mendeteksi Manajemen Laba Pada Perusahaan Manufaktur yang Terdaftar di Bursa Efek Jakarta. Variabel independen dalam penelitian ini yaitu beban pajak tangguhan sedangkan manajemen laba sebagai variabel dependen. Populasi yang digunakan dalam penelitian ini adalah perusahaan manufaktur yang terdaftar di BEJ tahun 1999 sampai 2002. Hasil Penelitian ini menunjukan bahwa pengukuran manajemen laba (akrual dan beban pajak tangguhan) memiliki pengaruh yang positif dan signifikan terhadap probabilitas perusahaan melakukan manajemen laba untuk menghindari kerugian.

Zulaikha Suranggane (2007) dengan judul Analisis Aktiva Pajak Tangguhan dan Akrual Sebagai Prediktor Manajemen Laba Kajian Empiris Pada Perusahaan Manufaktur di Bursa Efek Indonesia. Variabel independen dalam penelitian ini yaitu aktiva pajak tangguhan dan akrual sedangkan manajemen laba sebagai variabel dependen. Populasi yang digunakan dalam penelitian ini adalah perusahaan manufaktur yang terdaftar di BEJ tahun 2003 sampai 2005. Hasil Penelitian ini menunjukan bahwa variabel akrual memiliki pengaruh signifikan pada terjadinya manajemen laba, sedangkan cadangan aktiva pajak tanguhan tidak berpengaruh.

Ada pun tujuan penelitian ini adalah: 1) Untuk menjelaskan pengaruh aset pajak tangguhan terhadap manajemen laba pada perusahaan manufaktur di Bursa Efek Indonesia tahun 2010-2014; 2) Untuk menjelaskan pengaruh beban pajak tangguhan terhadap manajemen laba pada perusahaan manufaktur di Bursa Efek Indonesia tahun 2010-2014; dan 3) Untuk menjelaskan pengaruh aset pajak tangguhan dan beban pajak tangguhan terhadap manajemen laba pada perusahaan manufaktur di Bursa Efek Indonesia tahun 2010-2014. 


\section{Landasan Teori}

\subsection{Teori Agensi dan Manajemen Laba}

Dalam teori agensi (agency theory) menunjukkan hubungan antara principal (pemilik) dan agent (manajemen). Pemilik atau para pemegang saham mendelegasikan kewenangannya kepada manajemen untuk mengelola perusahaan. Pemilik diasumsikan hanya tertarik pada pengembalian keuangan yang diperoleh dari investasi mereka kepada perusahaan. Sedangkan manajemen diasumsikan akan menerima kepuasan tidak hanya dari kompensasi keuangan tetapi juga dari tambahan lain yang terlibat dalam hubungan keuangan. Sesuai dengan asumsi tersebut, maka manajer akan mengambil kebijakan yang menguntungkan dirinya sebelum memberikan manfaat kepada pemegang saham (Stella Mettawidya, 2015). Cara yang biasa dilakukan oleh manajemen adalah dengan merekayasa laporan keuangan dengan mempercantik laba atau yang biasa dikenal dengan manajemen laba.

Beberapa tujuan manajemen melakukan manajemen laba adalah menghindari rugi, pelaporan penurunan laba, avoiding failing meet or beat analyst forecast, dan invoke an earnings big bath [Bauman, et al (2001) dalam Zulaikha Suranggane (2007)].

\subsection{Pajak Tangguhan}

Antara akuntansi pajak dan keuangan memiliki tujuan yang sama, yaitu untuk menetapkan hasil operasi bsnis dengan pengukuran dan pengakuan penghasilan serta biaya. Karena dasar pengenaan penghasilan dan biaya untuk keperluan penghitungan Pajak Penghasilan berbeda dengan basis penghitungan untuk keperluan komersial maka terdapat perbedaan yang cukup signifikan antara akuntansi pajak dan keuangan.

Perbedaan tersebut terjadi karena adanya beda tetap dan sementara. Beda tetap, yaitu perbedaan yang disebabkan oleh adanya perbedaan pengakuan pendapatan dan beban antara Standar Akuntansi dan Peraturan Perpajakan. Dari perbedaan tersebut mengakibatkan perbedaan besarnya laba bersih sebelum pajak dengan laba fiskal atau penghasilan kena pajak. Beda tetap tidak mengakibatkan timbulnya pajak tangguhan.

Sedangkan beda sementara sebenarnya secara keseluruhan pendapatan atau beban antara akuntansi dan pajak sama, hanya berbeda alokasinya setiap tahun. Perbedaan ini berasal dari adanya perbedaan akrual dan realisasinya, penyusutan, amortisasi, dan kompensasi kerugian fiskal antara akuntansi dan perpajakan. Dari beda waktu tersebut muncul aset atau kewajiban pajak tangguhan.

Pengakuan aset atau kewajiban pajak tangguhan didasarkan fakta bahwa adanya kemungkinan pemulihan aset atau pelunasan kewajiban yang mengakibatkan pembayaran pajak periode mendatang menjadi lebih kecih atau besar. Apabila akan terjadi pembayaran pajak yang lebih besar di masa yang akan datang, maka berdasarkan standar akuntansi keuangan harus diakui sebagai suatu kewajiban. Dan, apabila ada kemungkinan pembayaran pajak yang lebih kecil pada masa yang akan datang, maka berdasarkan standar akuntansi keuangan, harus diakui sebagai suatu aset. Dari uraian di atas dapat disimpulkan bahwa:

1. Apabila Penghasilan Sebelum Pajak (komersil) lebih besar dari Penghasilan Kena Pajak (fiskal) akan mengakibatkan Beban Pajak Komersil lebih besar dari Pajak 
Terhutang/Pajak Kini (Tax

Payable). Dari hal tersebut akan menghasilkan Kewajiban Pajak Tangguhan (Deferred Tax Liability). Kewajiban ini dapat dihitung dengan mengalikan jumlah perbedaan temporer dengan tarif pajak.

2. Apabila Penghasilan Sebelum Pajak (komersil) lebih kecil dari Penghasilan Kena Pajak (fiskal) akan mengakibatkan Beban Pajak Komersil lebih kecil dari Pajak Terhutang.

\section{Metode Penelitian}

Metode analisis data yang digunakan dengan menggunakan analisis regresi linier berganda. Kemudian dilakukan Uji Asumsi Klasik yang terdiri dari Uji Normalitas, Uji Multikolinearitas, Uji Heteroskedastisitas, dan Uji Autokorelasi. Selanjutnya dilakukan uji hipotesis yang terdiri dari Analisis Determinasi, Uji Parsial (Uji t), Uji Simultan (Uji F).

\section{Hasil dan Pembahasan \\ 3.1. Uji Regresi Linier Berganda}

Tabel 1.

Analisis Regresi Linier Berganda Coefficients $^{a}$

\begin{tabular}{|c|c|c|c|c|c|}
\hline \multirow[t]{2}{*}{ Model } & \multicolumn{2}{|c|}{$\begin{array}{c}\text { Unstandardized } \\
\text { Coefficients }\end{array}$} & $\begin{array}{l}\text { Standardized } \\
\text { Coefficients }\end{array}$ & \multirow[t]{2}{*}{$\mathrm{t}$} & \multirow[t]{2}{*}{ Sig. } \\
\hline & $B$ & Std. Error & Beta & & \\
\hline (Constant) & 9,870 & 3,070 & & 3,215 & ,002 \\
\hline Aset Pajak Tangguhan $(\mathrm{X} 1)$ & ,475 &, 144 & ,081 & 3,289 & ,002 \\
\hline Beban Pajak Tangguhan(X2) & $-1,104$ & ,027 & $-1,008$ & $-41,019$ &, 000 \\
\hline
\end{tabular}

a. Dependent Variable: Manajemen Laba(Y)

Sumber: Hasil Pengolahan Data dengan SPSS 21.0, (2015)

Berdasarkan hasil analisis Tabel 1 di atas, maka dapat dibuat model persamaan regresi linier berganda sebagai berikut:

$\mathrm{Y}=\mathrm{a}+\mathrm{b}_{1} \mathrm{X}_{1}+\mathrm{b}_{2} \mathrm{X}_{2}$

$Y=9,870+0,475 X_{1}-1,140 X_{2}$

Keterangan :

$\mathrm{Y}=$ Manajemen Laba

$\mathrm{a}=$ Konstanta

$\mathrm{X}_{1}=$ Aset Pajak Tangguhan

$\mathrm{X}_{2}=$ Beban Pajak Tangguhan

$\mathrm{b}_{1}=$ Koefisien Regresi Aset Pajak

Tanguhan

$\mathrm{b}_{2}=$ Koefisien Regresi Beban Pajak Tangguhan

Berdasarkan Tabel 2 dan persamaan regresi linear berganda di atas, dapat dijelaskan sebagai berikut:

1. Konstanta $\mathrm{a}=0,9870$
Nilai ini akan dilakukan anti log yaitu dengan cara pada program Ms Excel "=EXP(0,9870)" denga hasil 2,6831 Artinya jika aset pajak tangguhan dan beban pajak tangguhan adalah 0 , maka besarnya manajemen laba adalah 2,6831.

2. Aset Pajak Tangguhan Terhadap Manajemen Laba

Nilai koefisien regresi varibel aset pajak tangguhan $\left(b_{1}\right)$ bernilai positif yaitu 0,475 . Artinya jika nilai aset pajak tangguhan ditingkatkan sebesar 1 satuan, maka manajemen laba akan meningkat sebesar 0,475. Koefisien aset pajak tangguhan bertanda positif, hal ini menujukkan bahwa aset pajak tangguhan berhubungan positif dengan 
manajemen laba pada perusahaan manufaktur di Bursa Efek Indonesia. Dari koefisien aset pajak tangguhan tersebut maka dapat disimpulkan bahwa jika aset pajak tangguhan bernilai positif maka manajemen laba pun akan naik.

3. Beban Pajak Tangguhan Terhadap Manajemen Laba

Nilai koefisien regresi varibel beban pajak tangguhan $\left(b_{2}\right)$ bernilai negatif yaitu $-1,140$. Artinya jika nilai beban pajak tangguhan ditingkatkan sebesar 1 satuan, maka manajemen laba akan menuruun sebesar -1,140. Koefisien beban pajak tangguhan bertanda negatif, hal ini menujukkan bahwa beban pajak tangguhan berhubungan negatif dengan manajemen laba pada perusahaan manufaktur di Bursa Efek Indonesia. Dari koefisien beban pajak tangguhan tersebut maka dapat disimpulkan bahwa jika beban pajak tangguhan bernilai negatif maka manajemen laba pun akan turun.

\subsection{Uji Koefisien Determinasi}

Tabel 2

Uji Koefisien Determinasi

Model Summary

\begin{tabular}{|l|r|r|r|c|}
\hline Model & $\mathrm{R}$ & $\mathrm{R}$ Square & Adjusted R Square & $\begin{array}{c}\text { Std. Error of the } \\
\text { Estimate }\end{array}$ \\
\hline 1 &, $982^{\mathrm{a}}$ &, 965 &, 964 & 1,8595002 \\
\hline
\end{tabular}

a. Predictors: (Constant), Beban Pajak Tangguhan (X2), Aset Pajak Tangguhan (X1)

b. Dependent Variable: Manajemen Laba $(Y)$

Sumber: Hasil Pengolahan Data dengan SPSS 21.0, (2015)

Koefisien determinasi dari perhitungan Tabel 2 di atas diperoleh angka sebesar 0,965. Hal ini menunjukkan bahwa besar sumbangan pengaruh aset pajak tangguhan dan beban pajak tangguhan terhadap manajemen laba yaitu $96,5 \%$ sedangkan sisanya sebesar $3,5 \%$ dipengaruhi oleh faktor lain yang tidak diteliti.

\subsection{Uji t (Uji Koefisien Regresi Secara Parsial)}

Tabel 3

Uji Koefisien Regresi Secara Parsial (Uji T) Coefficients $^{\mathrm{a}}$

\begin{tabular}{|l|r|r|r|r|r|}
\hline Model & \multicolumn{2}{|c|}{$\begin{array}{c}\text { Unstandardized } \\
\text { Coefficients }\end{array}$} & $\begin{array}{c}\text { Standardized } \\
\text { Coefficients }\end{array}$ & \multirow{2}{*}{ Sig. } \\
\cline { 2 - 4 } & \multicolumn{1}{|c|}{ B } & Std. Error & Beta & \\
\hline \multirow{2}{*}{ (Constant) } & 9,870 & 3,070 & & 3,215 &, 002 \\
Aset Pajak Tangguhan(X1) &, 475 &, 144 &, 081 & 3,289 &, 002 \\
Beban Pajak Tangguhan $(\mathrm{X} 2)$ & $-1,104$ &, 027 & $-1,008$ & $-41,019$ &, 000 \\
\hline
\end{tabular}

a. Dependent Variable: Manajemen Laba(Y)

Sumber: Hasil Pengolahan Data dengan SPSS 21.0, (2015)

Analisis uji t berdasarkan Tabel 3 adalah sebagai berikut:
1. Pengaruh Aset Pajak Tangguhan Terhadap Manajemen Laba. Untuk nilai $t_{\text {hitung }}$ dan $t_{\text {tabel }}$ pada variabel aset 
pajak tangguhan mempunyai $t_{\text {hitung }}$ sebesar 3,2897 maka diperoleh hasil $t_{\text {hitung }}>t_{\text {tabel }}$ atau $3,2897>1,9957$ maka $\mathrm{H}_{0}$ ditolak yang berarti aset pajak tangguhan secara parsial berpengaruh terhadap manajemen laba.

2. Pengaruh Beban Pajak Tangguhan Terhadap Manajemen Laba. Untuk nilai $t_{\text {hitung }}$ dan $t_{\text {tabel }}$ pada variabel beban pajak tangguhan mempunyai $t_{\text {hitung }}$ sebesar $-41,019$ maka diperoleh hasil $\mathrm{t}_{\text {hitung }}<\mathrm{t}_{\text {tabel }}$ atau $-41,019<$ 1,9957 maka $\mathrm{H}_{0}$ diterima yang berarti beban pajak tangguhan secara parsial tidak berpengaruh terhadap manajemen laba.

\subsection{Uji F (Uji Koefisien Regresi Secara Bersama-sama)}

Seluruh variabel independen dapat dikatakan memiliki pengaruh secara bersama-sama terhadap variabel dependen jika nilai $F$ hitung lebih besar dari $\mathrm{F}$ tabel atau jika nilai signifikansinya lebih kecil dari 0,05 .

Tabel 4

Uji Koefisien Regresi Secara Simultan (Uji F) ANOVA $^{\mathrm{a}}$

\begin{tabular}{|l|r|r|r|r|r|}
\hline Model & Sum of Squares & df & Mean Square & F & Sig. \\
\hline Regression & 6310,897 & 2 & 3155,448 & 912,575 &, $000^{\circ}$ \\
1 Residual & 231,669 & 67 & 3,458 & & \\
Total & 6542,565 & 69 & & & \\
\hline
\end{tabular}

a. Dependent Variable: Manajemen Laba(Y)

b. Predictors: (Constant), Beban Pajak Tangguhan(X2), Aset Pajak Tangguhan(X1)

Sumber: Hasil Pengolahan Data dengan SPSS 21.0, (2015)

Berdasarkan Tabel 4 di atas dapat di lihat bahwa secara simultan $F_{\text {hitung }}>$ $F_{\text {tabel }}$ atau 912,575>3,13. Sehingga dapat disimpulkan bahwa variabel independen dalam penelitian ini, yaitu aset pajak tangguhan dan beban pajak tangguhan secara simultan atau keseluruhan memiliki pengaruh terhadap manajemen laba.

Berdasarkan hasil pengujian diatas, maka di bawah ini penulis menginterpretasikan hasil penelitian yang diperkuat dengan hasil penelitianpenelitian sebelumnya sebagai berikut:

1. Aset pajak tangguhan memiliki pengaruh terhadap manajemen laba pada perusahan manufaktur di Bursa Efek Indonesia tahun 2010-2014. Aset pajak tangguhan dijadikan proksi sebagai indikator dari praktik menajemen laba yang dilakukan perusahaan. Aset pajak tangguhan yang jumlahnya diperbesar oleh manajemen dimotivasi untuk minimalisasi pembayaran pajak agar tidak merugikan perusahaan. Pajak yang seharusnya dibayarkan pada periode sekarang dialihkan pada periode mendatang dengan demikian laba perusahaan pun akan meningkat karena beban pajak yang harus dibayarkan lebih kecil. Hasil penelitian ini tidak konsisten dengan penelitian yang dilakukan oleh Zulaikha Suranggane (2007) menyatakan bahwa aset pajak tangguhan tidak berpengaruh dalam melakukan manajemen laba.

2. Beban pajak tangguhan tidak memiliki pengaruh terhadap manajemen laba pada perusahan manufaktur di Bursa Efek Indonesia 
tahun 2010-2014. Perusahaan manufaktur di Indonesia yang memanfaatkan celah untuk memenaj labanya dengan menggunakan besarnya beban pajak tangguhan pada laporan laba rugi fiskalnya akan terkoreksi dalam laporan laba rugi fiskal. Peraturan perpajakan memberikan batasan lebih ketat dalam penghitungan pajaknya hanya mengakui besarnya penghasilan atau biaya pada saat di terima atau dikeluarkan sebagai dasar dalam penghitungan laba rugi fiskalnya. Dengan kata lain perpajakan hanya mengakui beban pajak pada periode tersebut dan tidak mengakui adanya beban pajak tangguhan. Hasil penelitian ini tidak konsisten dengan penelitian yang dilakukan oleh Yulianti (2005), Subekti Djamaluddin, Rahmawati, Handayani Tri Wijayanti (2008) dan Ardi Hamzah (2010) bahwa beban pajak tangguhan berpengaruh terhadap manajemen laba.

\section{Penutup}

Berdasarkan pembahasan di atas, maka dapat diambil beberapa kesimpulan, yaitu:

1. Hasil penelitian ini menunjukan bahwa nilai variabel aset pajak tangguhan yaitu $t_{\text {hitung }}>t_{\text {tabel }}$ atau $3,2897>1,9957$ artinya aset pajak tangguhan secara parsial berpengaruh terhadap manajemen laba pada perusahaan manufaktur di Bursa Efek Indonesia tahun 2010-2014. Apabila aset pajak tangguhan mengalami kenaikan maka manajemen laba pun akan mengalami kenaikan.

2. Hasil penelitian ini menunjukan bahwa nilai variabel beban pajak tangguhan yaitu $\mathrm{t}_{\text {hitung }}<\mathrm{t}_{\text {tabel }}$ atau $41,019<1,9957$ artinya beban pajak tangguhan secara parsial tidak berpengaruh terhadap manajemen laba pada perusahaan manufaktur di Bursa Efek Indonesia tahun 20102014. Apabila beban pajak tangguhan mengalami kenaikan maka manajemen laba akan mengalami penurunan.

3. Hasil penelitian ini menunjukan bahwa nilai variabel aset pajak tangguhan dan beban pajak tangguhan yaitu $F_{\text {hitung }}>F_{\text {tabel }}$ atau 912,575 > 3,13 artinya aset pajak tangguhan dan beban pajak tangguhan secara simultan memiliki pengaruh terhadap manajemen laba pada perusahaan manufaktur di Bursa Efek Indonesia tahun 2010-2014. Koefisien determinasi dari penelitian ini diperoleh angka sebesar 0,965. Hal ini menunjukkan bahwa besar sumbangan pengaruh aset pajak tangguhan dan beban pajak tangguhan terhadap manajemen laba yaitu 96,5\% sedangkan sisanya sebesar $3,5 \%$ dipengaruhi oleh faktor lain yang tidak diteliti.

\section{Daftar Pustaka}

Ardi Hamzah. 2009. Deteksi Earning Management Melalui Beban Pajak Tangguhan, Akrual, dan Arus Kas Operasi (Studi Pada Peruasahaan Real Estate dan Property yang Terdaftar di Bursa Efek Indonesia Tahun 2006-2008). Jurnal Akuntansi dan Keuangan Indonesia.

Brigham dan Houston. 2010. DasarDasar Manajemen Keuangan.Buku 1 Edisi 1. Salemba Empat. Jakarta.

Diana Sari. 2014. Perpajakan Konsep, Teori dan Aplikasi Pajak Penghasilan. Mitra Wacana Media. Jakarta.

Djoko Muljono, dan Baruni Wicaksono. 2009. Akuntansi Pajak Lanjutan. Andi. Yogyakarta.

Duwi Priyatno. 2013. Analisis Korelasi,Regresi, dan Multivariate 
dengan SPSS. Gava Medi. Yogyakarta.

Edy Suprianto. 2011. Akuntansi Perpajakan. Graha Ilmu. Yogyakarta.

Gunadi. 2009. Akuntansi Pajak Edisi Revisi. Grasindo.

Hery. 2013. Akuntansi Keuangan Menengah, Center of Academic Publishing Service. Yogyakarta.

Hery. 2014. Akuntansi Perpajakan. Grasindo. Jakarta

Irham Fahmi. 2014. Manajemen Keuangan Perusahaan dan Pasar Modal. Mitra Wacana Media. Jakarta

Irreza. 2012. Pengguna Komponen Pembentuk Pajak Tangguhan Dalam Mendeteksi Manajemen Laba. Jurnal Akuntansi dan Keuangan Indonesia.

Mangarimpun. 2009. Materi Kuliah Online Pajak Kini dan Pajak Tangguhan. FE Universitas Esa Unggul. Tersedia di https://rimpun.files.wordpress.com/ 2012/03/materi-kuliah-online-taxplan.pdf.

Mc Gee. 1984. Accounting For Income Taxes, National Association Of Accountants 10 Paragon Drive Montvale. New Jersey.

Pernyataan Standar Akuntansi Keuangan. 2012. Ikatan Akuntan Indonesia.

Sofyan Yamin, Lien A. Rachmach, Heri Kurniawan. 2011. Regresi dan Korelasi Dalam Genggaman Anda. Salemba Empat. Jakarta.

Stella Mettawidya. 2015. Analisis Pengaruh Aset Pajak Tangguhan, Asimetri Informasi, dan Ukuran Perusahaan terhadap Manajemen Laba pada Perusahaan LQ45 yang Terdaftar di BEI pada Tahun 20102012. JOM FEKON Vol 2 No. 1.
Stice, Stice, Skousen. 2009. Akuntansi Keuangan, Edisi 16. Salemba Empa., Jakarta.

Subekti Djamaluddin, Rahmawati, dan Handayani Tri Wijayanti. 2008. Analisis Perubahan Aktiva Pajak Tangguhan dan Kewajiban Pajak Tangguhan Untuk Mendeteksi Manajemen Laba. Jurnal Akuntansi dan Manajemen.

Sugiyono. 2013. Statistika Untuk Penelitian. Alfabeta. Bandung.

Sugiyono. 2011. Metode Penelitian Kuantitatif, Kualitatif, dan $R \& D$. Alfabeta. Bandung.

Sukrisno Agoes, dan Estralita Trisnawati. 2009. Akuntansi Perpajakan. Edisi 3. Salemba Empat. Jakarta.

Tulis S. Meliala dan Francisca Widianti Oetomo. 2008. Perpajakan dan Akuntansi Pajak. Edisi 5. Semesta Media. Jakarta.

Waluyo. 2009. Akuntansi Pajak Edisi 2. Salemba Empat. Jakarta.

Yulianti. 2005. Kemampuan Beban Pajak Tangguhan Dalam Mendeteksi Manajemen Laba. Jurnal Akuntansi dan Keuangan Indonesia. Departemen Akuntansi Fakultas Ekonomi Universitas Indonesia.

Zulaikha Suranggane. 2007. Analisis Aktiva Pajak Tangguhan dan Akrual Sebagai Prediktor Manajemen Laba: Kajian Empiris Pada Perusahaan Manufaktur Yang Terdaftar Di BEJ. Jurnal Akuntansi dan Keuangan Indonesia. 